\title{
BASING-POINT AND FREIGHT-ZONE PRICE SYSTEMS UNDER THE ANTI-TRUST LAWS
}

\author{
JAMES R. WITHROW, JR. $\dagger$
}

The report of the Federal Trade Commission to the President on Steel Sheet Piling, ${ }^{1}$ the Wheeler Anti-Basing Point Bill, ${ }^{2}$ and the Government's attitude toward uniform prices ${ }^{3}$ again focus the attention of businessmen on the legality, as well as the commercial value, of basing point or freight zoning systems. There has been a pronounced trend in recent years for sellers to meet competition by adopting various more or less mechanical methods of dealing with freight costs in arriving at a final sale price. ${ }^{4}$ Thus, in an increasing number of industries the practice of employing "basing-point", "multiple basing-point", and "delivered-price" systems has become customary. ${ }^{5}$

The purpose of most of these systems has been, in the main, three-fold: ( I) to simplify figuring freight quotations; ${ }^{6}$ (2) to enlarge the market of a given manufacturer by enabling him to quote a price which, by absorbing some freight charges, will compete with (or by adding additional charges for freight will be identical to) that of another manufacturer whose factories are situated in some other locality (in other words, it is an attempt to eliminate geographical position as a substantial element in competition); and (3) to enable competitors to agree on, or otherwise to arrive at, uniform prices with

$\dagger$ A. B., 1932, LL. B., I935, Cornell University; member of the New York bar.

r. Fed. Trade Com., Report on Steel Sheet Piling, 1936. This report was referred by the President to the Attorney General on June 15, 1936, for appropriate action. N. Y. Times, June 22, 1936, p. I, col. I.

2. S. I58I, 75th Cong., Ist Sess. (1937), introduced February I7, 1937, 8I Cong. Rec., legis. day Feb. 15 , I937, at I562. This bill is identical with S. 4055, 74th Cong., 2d Sess. (r936), introduced January I6, I936, 80 CoNG. REC. 2408 (I936), and H. R. II329, 74th Cong., $2 d$ Sess. (1936), introduced on the same day, 80 CoNG. REC. 2534 (I936). See also a proposed amendment to Section 2 of the Clayton Act, H. R. 10486, 74th Con., 2d Sess. (1936). These Anti-Basing-Point bills are discussed in more detail infra, and see Hearings before Senate Committee on Interstate Commerce on S. 4055, 74th Cong., 2d Sess. (1936).

3. Id. at 286-288; see Editorial, N. Y. J. Comm., June 23, 1936, p. 2, col. I.

4. Fed. Trade Comm., supra note $I$, at 37-39.

5. The following industries use a zone price system: iron and steel, tobacco products, thread, stoves, mahogany, asphalt, mastic tiles, salt, bathtub, alcohol, coffee, soap, corn products, linseed products, cereal products, newsprint, paper, gasoline and oil products, wire and cable, valve and fittings.

The following industries use basing-point systems (or modifications thereof) : lumber, steel and iron, cement, zinc, corn products, copper, fertilizer, gasoline, lead, sugar, laundry machinery, crane and shovels, flour, range boilers, bolts, nuts and rivets, cast iron pipe, asphalt roofing, linseed oil. It should be noted that some materials are sold part on one and part on the other system. Generally speaking, the industries using such freight systems are those which have standardized products, or products which conventionally are of uniform grade and quality.

6. The United States parcels post service and the American Express Company both use zoning systems as a matter of convenience. 
greater ease, pursuant to some understanding between them. ${ }^{7}$ The first reason for using such systems is of undoubted legal validity. The second has been seriously questioned in this respect by the Federal Trade Commission, ${ }^{8}$ and the third is certainly prima facie illegal since it amounts to a violation of Section $I$ of the Sherman Act. ${ }^{9}$ These three are by no means the only advantages of such systems. In addition, there is for some products an advertising advantage in being able to offer a uniform price, and such systems eliminate the mechanical unwieldiness and the prohibitive cost of price schedules which would otherwise have to be translated from a maze of differing freight rates into a price schedule which would reflect those differences. ${ }^{10}$

The charge was repeatedly made by consumers, economists, and others ${ }^{11}$ that such methods of arriving at prices amounted to discrimination under the old Section 2 of the Clayton Act ${ }^{12}$ in that the sellers have, after making an allowance for the cost of transportation among their various customers, exacted higher prices from customers having little or no transportation expense and accepted lower prices from those having heavy transportation expense. The same argument against the validity of such practices will undoubtedly arise under the Robinson-Patman Act. ${ }^{13}$

Another criticism of such systems is that they result in the receiving by the Government and others of identical bids or price quotations from manufacturers. ${ }^{14}$ To blame such uniformity solely on delivered-price systems is to overlook the distinct possibility that prices on a standardized commodity will tend to be uniform if effective competition exists. It is, of course, apparent that such freight systems might be a great aid in helping to police price agreements, but the systems themselves might still not be illegal. It should perhaps be pointed out that mere uniformity of price is not per se illegal. Even uniformity of prices arrived at by merely "following the leader" is not illegal, except where there is an agreement or understanding

7. Fed. Trade Comm., supra note I.

8. See the following Fed. Trade Comm. reports: The Price of Gasolines in I9I5-I9I7, I9I8, at I49, I50, I53-I54, I56; The Advance in the Price of Petroleum Products, I920, at 54; Commercial Feeds, I921, at I20 n., I63-164; Lumber Manufacturers Trade Associations, I922, at I2I; Western Pine Manufacturers Association, I922; 2 Home Furnishings, 1923, at 89; Northern Hemlock \& Hardwood Manufacturers Association, 1923, at ix; Prices, Profits and Competition in Petroleum Industries, 1928, at 71 ; Newsprint Paper Industry, I930, at 37-44; Price Bases Inquiry: The Basing-Point Formula and Cement Prices, 1932; Basing-Point System in the Iron and Steel Industry, I934; Practices of the Steel Industry under the Code, I934; Range Boiler Industry, 1936; Steel Sheet Piling, 1936; and see Fed. Trade Comm., supra note I. See also Tariff Comm. Information Survey, Cotton Thread, I927.

9. 26 Stat. 209 (I890), I5 U. S. C. A. § I (I927).

ro. Supra note 6.

II. See especially Fetter, The Masquerade of Monopoly (I93I); Note (I932) 45 HARV. L. REV. 548.

r2. 38 STAT. 730 (I9I4), I5 U. S. C. A. \$ I3 (I927).

13. 49 Srat. 1526, I5 U. S. C. A. \& I3 (Supp. 1936).

14. Fed. Trade Comm., supra note I, at 286-288, where Secretary of the Interior Ickes lists some 48 industries where identical prices have been bid. 
among competitors that they will do so. ${ }^{15}$ This type of economic discrimination may properly be called geographical discrimination, because the amount of transportation service provided varies as between different customers. Geographical discrimination may be said to exist whenever sale prices, after the proper deduction of transportation costs (which are usually capable of being exactly determined), yield net prices at the factory or warehouse which differ because of the geographical location of buyers. ${ }^{16}$ Such discrimination would cease to exist only when the net at the point of shipment received from all sales would be uniform at a given time. The fact that such practices often result in economic discriminations does not render them illegal under the Anti-Trust Laws.

The systems which are employed so as to manage or manipulate freight costs are numerous, the best known being the so-called PittsburghPlus plan ${ }^{17}$ of the steel industry. The old Pittsburgh-Plus was a basingpoint system by which steel products were sold at a price equal to the factory price plus the actual cost of freight from Pittsburgh to any destination. This freight charge from Pittsburgh was added even though the steel may not have been actually shipped from there, with the result that purchasers in Chicago paid freight from Pittsburgh, although the steel would probably be shipped from the neighboring mills at Gary, Indiana. Custom, central location, and superior competitive position were probably instrumental in the establishment of Pittsburgh as the steel basing-point, and the custom was solidified by agreement or understanding or for the sake of convenience, even after some of the more fundamental reasons for its establishment had ceased to exist.

The single basing-point system was one of the earliest methods of arriving at an artificial equalization of freight charges. The need for added basing-points due to competition from factories in new localities has led to the so-called multiple basing-point system, wherein prices are determined as of the basing point nearest to the purchaser. Other systems are to sell on a

I5. United States v. International Harvester Co., 274 U. S. 693 (I927). The court states: "And the fact that competitors may see proper, in the exercise of their own judgment, to follow the prices of another manufacturer, does not establish any suppression of competition or show any sinister domination." Id. at 709. Compare also Pacific States Paper Trade Ass'n v. Federal Trade Comm., 4 F. (2d) 457 (C. C. A. 9th, 1925), modified, 273 U. S. 52 (I927).

16. There are, of course, methods of arriving at a varying mill-net price other than the use of basing-point, freight-zone or delivered-price systems. Rebates, special freight allowances, or varying charges for freight pickups may be utilized so as to reach the same result. In general the legality of such rebates may be seriously doubted, especially under the Robinson-Patman Act. This subject will, however, not be considered herein.

17. Berglund, The United States Steer Corporation (I907) 164-I67; Krentzberg, The Passing of "Pittsburgh Plus" (I924) I7 AMr. BANkers A. J. 30r. No detailed history of the origin of Pittsburgh-Plus is available; testimony before the Federal Trade Commission in Matter of the United States Steel Corporation, 8 FED. TRADE ComMr. DEC. (I924) I, indicates that it was in use in the sale of beams in 1880, but was not generally applied until after the formation of the United States Steel Corporation in I90I. By I907 it was well established. BERGLUND, loc. cit. supra. 
flat delivered price for a given area or for the entire country, or to divide the country into freight zones and sell products at a uniform delivered price for each zone. All of these systems have much the same purpose and in general operate with similar effect, although the economic situation in some industries seemed to make one system more adaptable than another.

Any discussion of the law of such freight systems requires a clear understanding of the economic background of the various practices. ${ }^{18}$ The Supreme Court has repeatedly pointed out the necessity of clearly understanding the factual background in each anti-trust case. ${ }^{19}$ For that reason the facts which are typical of a number of manufacturing industries will be set forth briefly.

The manufacturers in these industries, which in the main had grown up along the Atlantic seaboard, originally sold their products f. o. b. factory, charging the actual freight to the destination if a delivered price were desired. By the early years of the twentieth century some companies had varied this method of arriving at a sale price, so that some large producers sold at a uniform delivered price in each state, while others sold on actual freight east of the Mississippi River and had adopted a modified basing-point system west of the Mississippi. During the World War the War Industries Board adopted a plan in placing orders for cantonment camps in order to insure an adequate supply of necessary materials. The Board also approved a zoning plan for certain industries, apparently with the thought that this was also necessary in order to insure an adequate supply of equipment. After the War and the depression of 1920 , the practices of these industries were rapidly becoming more uniform in sales of competing products. Products which were smaller in size and weight, since they were not subject to such noticeable price variations when the actual freight was charged, generally used a close approximation to the actual freight rates from the points of production to those of consumption. The larger and heavier products, for which price variations due to freight costs were substantial, came to be sold by most producers on a basing-point or a freight-zone system.

The N.R. A. took no stand on the question of geographical discrimination in price. ${ }^{20}$ As a result, a number of the codes provided for freight-zone,

I8. For a good discussion of the general economic background of such freight systems see Burns, The Decline of CoMpetition (I936) 280-37I.

I9. Appalachian Coals v. United States, 288 U. S. 344, 360-36I (1933) ; Sugar Institute v. United States, 297 U. S. 553 (1936).

20. But see Richberg's remarks in Hearings before Senate Committee on Interstate Commerce, supra note 2 , at 85-86: "It was our observation, and it was the opinion of the experts outside whose aid we obtained, that a basing-point system in which every producing area was a basing point would be a sound and economical system and good business practice. In other words, if there were a lot of mills within a small radius of 25 to 50 miles of Pittsburgh, as a business practice there was nothing wrong, and a great deal of convenience and benefit in having one basing point for that area. The evil in the basing-point system that seemed to me evident from the beginning, and which I think is partly historical growth and partly the result 
basing-point, or delivered-price systems. ${ }^{21}$ In industries such as lumber, cement and insulated cable, where these practices had become an industry custom or practice before the codes, they were continued under them, and the practices became more standardized due to the existence of open price filing provisions in the codes. All of the N. R. A. codes had a pronounced effect upon their respective industries in crystallizing and unifying industry practices, especially if they provided for open price filing. ${ }^{22}$ The termination of the N. R. A. era, therefore, generally left industry practices stabilized.

The fact that most of the factories in many industries were located in New York, New Jersey, Pennsylvania and Connecticut seemed to aid those industries in arriving at freight systems. The freight zones, then, which these industries used, represented places which would have had approximately equal freight rates for goods shipped from New York City, and the freightzone charges were approximations of actual freight costs. As factories were built in other sections of the country, freight-zone charges bore less relation to the actual costs of transportation.

When basing-point or freight-zone systems are employed, prices are generally quoted on a delivered-price basis. As a result, customers are not aware of how much of the final price is in fact a charge for freight. ${ }^{23}$ Under these systems each manufacturer defrays at times a part of the actual transportation costs; at other times he may receive more than the actual freight costs if he is located near the consumer, and he charges the railroad freight from some recognized center of production or an average zone freight rate.

The trend in these industries, as in many others, has been to charge transportation cost on products which were light in weight and easy to ship at the actual freight rate, or else to use a flat delivered price for the entire country, since in either case competitors having similar factory prices would have comparable prices $f . o$. b. the customer's city. With heavier or bulkier items, since the differences in price would vary considerably with the distance from the customer's city, and the manufacturer nearest any given purchaser had such an advantage, competitors were forced to (I) abandon their efforts to compete; (2) lower their factory price so that that price plus freight was competitive; or (3) maintain the current factory price in appear-

of the power of certain large interests in the industry, has been the denial of basing points to certain producing areas that ought to have basing points, and, as a result, the establishment of artificial basing points in nonproducing areas, giving a special advantage to the producing areas which did have basing points."

2x. Six codes provided for freight systems. They were: Fertilizer, Petroleum, Business Furniture, Storage and Filing Equipment, Salt, and Shovel Dragline and Crane. Five codes provided for basing-points. They were: Cast Iron Pipes, Iron and Steel, Lime, Refractories, and Reinforcing Materials. Thirty-three other codes provided for delivered prices of some kind. For further material see Consumer Advisory Board, Appendices to Memorandum to General Johnson, Feb. 19, I934.

22. Fed. Trade Comm., supra note I, at 6 .

23. Hearings before Senate Committee on Interstate Commerce, supra note 2 , at 322. 
ances and absorb some or all of the freight charges. The manufacturers in many industries chose to employ the third alternative as long as they could realize a sufficient price on their product to pay the current costs of production plus transportation and a proportion of their current obligations on their fixed charges.

Manufacturers believed, and no doubt they arrived at their belief through sad experience, that it was virtually impossible to maintain one factory price for customers located close to a factory while maintaining progressively lower prices as the customer's situs approached the factory of an effective competitor. All customers on learning of the lower price would demand it and feel entitled to it. Delivered-price policies, basing-points and freight zones were all devised to enable the manufacturer to quote competitive prices in a district close to a competitor's factory without apparently reducing the factory prices.

Freight-zone policies had to be strictly adhered to or they would break down. If purchasers were allowed to have goods shipped to a point in one zone, and were then to pay the actual freight to another zone, the resultant price might be less than the delivered price to that zone, and the system would crumble of its own weight. As a result, sellers never quoted any price other than that of the customer's city, and a purchaser was not allowed to purchase f. o. b. manufacturer's mill except at a price equal to that which would have been charged at the ultimate destination. As a logical result, allowances were often not made to purchasers even though the goods were shipped by water or by other methods cheaper than the standard all-rail freight. Manufacturers seemed to feel that these delivered-price practices were necessary in order to maintain their system, since purchasers would always have taken the cheaper alternative and thus have made the manufacturer absorb a larger proportion of the freight charge on distant shipments, preventing him in some cases from equalizing the freight charges among all of his customers.

Economically, and presumably legally, identical problems are presented by flat delivered prices and by freight-zone adders, provided all the plants manufacturing the product are to be found in one single zone. The problems are identical because the price in the basic zone, where the factories are located, is a flat delivered price. As far as zones other than the basic one are concerned, since the freight zones have increasing freight charges, the resulting price more nearly equals the mill price plus the actual freight. Freight zones are, therefore, at least in part a recognition of the fact that freight costs may be competitive elements. Flat delivered-price systems and basing-point systems where the factory is not located at or near the basingpoint represent a wider departure from the so-called pure competitive posi- 
tion, since the actual freight in the price of the article has little to do with the actual cost of the freight.

The location of plants outside the basic zone which charge basic zone prices plus freight from that zone would seem to be economically unjustifiable unless costs of production are higher. Such manufacturers must consider, before lowering their prices, that these lower price levels would compel competing manufacturers to install branch factories which would overexpand the production in that area and might lead to an even smaller volume of busiiness. The factory located nearer to certain customers has an advantage in the point of delivery time which is bound to give him a sufficient volume of business in a stabilized market.

The contention has been made that free competition can exist only if goods are sold at a price equivalent to the cost plus profit at the point of shipment plus the actual cost of freight to the destination, and that any other practices involve illegal discrimination. ${ }^{24}$ Acceptance of this assumption would involve the prohibition of selling goods over any area, however small, at a flat delivered price. The argument that flat delivered prices for any given area prevent customers from freely competing with each other at the point of production has some merit, provided it is not carried to its logical but absurd extreme of requiring a department store to make varying delivery charges to customers living in the same urban area. When viewed on a national scale, it is apparent that such systems must necessarily operate in certain instances to discriminate against customers adjacent to the point of production (or near freight zone lines), since they may be required to buy goods and freight when they are interested solely in buying goods. ${ }^{25}$ Those advocating this contention then point out that the result of this system is wasteful cross-freighting, in that it enables manufacturers to compete outside the spheres surrounding their factories. This evil of cross-freighting has certainly been overemphasized, ${ }^{26}$ although its full extent would be ascertained only if a thorough study

24. This contention was made by Fetter, Commons, and Ripley as expert witnesses for the Federal Trade Commission in Matter of the United States Steel Corp., 8 FED. Trade CoMr. DeC. (I924) I.

25. A logical extension of these arguments would require a seller to itemize all his costs, and would make it illegal to sell below the total even to meet competition in good faith.

26. In Fertilizer Industry Price Filing Study, NRA Work Materials No. 67, at p. 33, it is stated that: "This very brief survey would indicate that cross-shipping between (freight) zones is not a very serious problem." In Fed. Trade Comm., The Basing Point Formula and Cement Prices, I932, at I34 et seq., it is estimated that the cross-haul in the cement industry results in a waste of $\$ 42,000,000$. The study, however, is not very complete, and is more in the nature of an estimate. See also Richberg in Hearings before Senate Committee on Interstate Commerce, supra note 2, at 86: "I want to say as a general proposition, which I believe to be correct, that for the consuming public as a whole, I think our investigations developed that more freight was absorbed than excess freight was charged. That is, in order to meet competition in these competing areas the producer has to absorb a great deal of freight; . . . as to the industry as a whole, in relation to its customers, we had one investigation made which showed a large excess in favor of the customers. That is, there was more freight absorbed than excess freight 
were made. Opponents of such systems also charge that they artificially maintain plants that were established under economic conditions which no longer exist. As a result, therefore, uneconomic factories are maintained in order to protect past investments. ${ }^{27}$ It is possible to agree, in the main, with these contentions insofar as they are demonstrations of pure economic theory, but it is another question when this economic theory is attempted to be read into the Anti-Trust Laws, since there are types of discrimination which are not subject to their operation. The basic legal question is whether or not the law sanctions only price policies which make proportional allowances for differences in the costs of transportation.

It has been found convenient to discuss the freight systems with reference to each of the Anti-Trust laws separately. The Sherman Act is considered first because of the fact that more cases bearing on this question are found under it, even though the Act is not primarily concerned with price discrimination.

\section{The SHerman Act}

Since the Sherman Act ${ }^{28}$ is primarily concerned with agreements, combinations, or conspiracies which restrain competition and trade, freight systems will be considered only when they are connected with such problems. A contract, agreement, combination, or conspiracy to arrive at a basing-point or other freight-destination system is a combination in restraint of trade and therefore illegal if it is unreasonably "restrictive of competitive conditions". ${ }^{29}$ It would seem that under most circumstances an agreement to sell solely by certain freight systems would be an illegal restraint because of its effect on free and effective competition between the agreeing parties.

In several Sherman Act cases it has been charged that the collection and distribution by a trade association of information which aided the use of freight systems and other uniform practices was an illegal restraint of trade. In the Maple Flooring ${ }^{30}$ and Cement ${ }^{31}$ cases, the Supreme Court held that the mere existence of basing-point systems and other uniform practices, in

charged. So that I think, from the standpoint of the industry in relation to consumers as a group, you cannot say that the consumers as a group have been forced to pay more freight than they have been saved.

27. Id. at $85-86$.

28. 26 STAT. 209 (I890), 15 U. S. C. A. \$ I (I927).

29. The "rule of reason" doctrine applies the standard that not every combination in restraint of trade is unlawful, but only those which were unreasonable or undue either because of their inherent nature or effect, or because of their evident purpose. Standard Oil v. United States, 22I U. S. I (I9II) ; United States v. American Tobacco Co., 22 I U. S. I06 (I9II) ; United States v. Terminal R. R. Ass'n, 224 U. S. 383 (I9I2); United States v. Union Pac. R. R., 226 U. S. 6I (I9I2). Thus a burden is placed upon the government to prove that the restraint of trade must be one involving an effective control of a substantial portion of an industry or it will fail in its prosecution. Standard Oil v. United States, 283 U. S. 163 (193I); Appalachian Coals v. United States, 288 U. S. 344 (I933).

30. Maple Flooring Mfrs. Ass'n v. United States, 268 U. S. 563 (1925).

3I. Cement Mfrs. Protective Ass'n v. United States, 268 U. S. 588 (I925). 
the absence of an agreement, express or implied, is not a violation of the Sherman Act. The Government brought the actions under the Act, alleging and proving many uniform practices among the manufacturers involved. Since the Clayton Act was not involved, the question of price discrimination by virtue of the basing-points was little stressed. The Supreme Court, however, did attempt to justify the basing-point practices and seemed willing to risk the danger of the establishment of uniform price agreements through the mechanism of basing-point systems. In view of the Court's language it is difficult to believe that it would condemn those systems under the old Section 2 of the Clayton Act. ${ }^{32}$ The Court stressed the fact that it was the custom of the trade to quote a delivered price and that purchasers would usually buy on no other basis. The Court described the basing-point system in the Maple Flooring case as follows:

"Through the agency of the Secretary of the Association a booklet was compiled and distributed to members of the Association showing freight rates from Cadillac, Michigan, to numerous points throughout the United States to which the finished flooring is shipped by members of the Association. It appears from the evidence to have been the usual practice in the maple flooring trade, to quote flooring at a delivered price and that purchasers of flooring usually will not buy on any other basis. The evidence, however, is undisputed that the defendants quote and sell on an f. o. b. mill basis whenever a purchaser so requests. It also appears that the mills of most of the members of the Association are located in small towns in Michigan and Wisconsin and that the average freight rates from these principal producing points in Michigan and Wisconsin to the principal centers of consumption in the United States are approximately the same as the freight rate from Cadillac, Michigan, to the same centers of consumption. There is abundant evidence that there were delays in securing quotations of freight rates from the local agents of carriers in towns in which the factories of defendants are located, which seriously interfered with prompt quotations of delivered prices to customers; that the actual aggregate difference between local freight rates for most of defendant's mills and the rate appearing in defendant's freight-rate book based on rates at Cadillac, Michigan, were so small as to be only nominal, and that the freight-rate book served a useful and legitimate purpose in enabling members to quote promptiy a delivered price on their product by adding to their mill price a previously calculated freight-rate which approximated closely to the actual rate from their own mill towns." 33

In the Maple Flooring case there was a single basing-point at Cadillac, Michigan, and all but two members of the association were located in Michigan or Wisconsin (one was in Illinois and the other in New York). On 
shipments to any distance the discrepancies between freight from the mill and freight from Cadillac were small. Within and near the region in which the mills were located the discrepancies would react against all the manufacturers fairly equally.

One significant statement in the quotation above must be emphasized before passing on to the Court's discussion of the legal effects of such a practice. This statement sets forth the fact that the manufacturers involved would quote a price f. o. b. mill whenever a purchaser requested such a quotation. Although the Court does not specially stress this fact in the opinion, it may readily be seen that such a practice would be an effective check on producers to make the freight rates quoted from the basing-point approximately the same as the actual freight rate from the place of manufacture. Without such a practical check on the difference between actual freight rates and freight rates from a basing-point the Court might consider any scheme in a much less favorable light.

In the Maple Flooring case the government based its criticism of the use of the freight-rate book on the ground that, although the Maple Flooring Association did not publish delivered prices in the freight book, the publishing of the freight-rate book and the circulation of tables of estimated cost of flooring effectively enabled the members of the association to arrive at a uniform delivered price by adding to the estimated cost the circulated freight rate. It was argued that this was merely a device so that a fixed minimum price would be maintained. The Court found that, although the data as to the available cost of flooring, together with the calculated freight rate, could readily be made the basis for a price-fixing agreement, nevertheless, there was no violation of the Sherman Act since it was not established that the defendants had entered into an agreement to use this material in that manner. It pointed out that the record presented solely the question of whether the use of this material would necessarily result in an unreasonable restraint of interstate commerce. In the absence of a purpose to monopolize or the compulsion that results from a combination or agreement, it felt that an individual could exercise great freedom in his activities without causing a restraint of trade. It was held, therefore, that no restraint had been proved in the Maple Flooring case.

The Cement case similarly involved the activities of a trade association which compiled and distributed freight-rate books among its members. The members of the Cement Association were all located in New York, New Jersey, Pennsylvania, Maryland and Virginia, in which area it was customary to employ four basing-points, Universal, Pa., Lehigh Valley, Pa., Hudson, N. Y., and Fordwick, Va. The freight-rate books gave the rate of freight from these four basing-points to numerous points of delivery within the ter- 
ritorial area served by the members of the association. These rates were compiled from official tariffs and translated from a rate per ton into a rate per barrel of cement so as to be in more convenient form. The Court found that prior to the existence of the association similar books were prepared by individual manufacturers at a greatly increased cost and with a greater possibility of error than existed when compiled on behalf of all of the individual manufacturers by the association. In its opinion it stressed the fact that it was the custom in the cement trade to sell cement on a "one price" or a delivered-price basis even prior to the organization of the defendant association, and that in every instance the basing-points were points of actual shipment from which the larger proportion of the cement in a given locality was actually shipped. The Court also found that these freight-rate books were a great convenience in quoting prices accurately and promptly.

The system in and of itself was held not to be a violation of the Sherman Act on the same grounds as were employed in the Maple Flooring case. The Court also discussed and apparently approved the use of the basingpoint system of pricing cement. One of the reasons for such a justification was the history of freight rates applied to competing mills in the Lehigh Valley. There the Interstate Commerce Commission established a blanket rate so that freight charges would be identical for competing mills. The multiple basing-point system of the cement industry merely amounted to each individual company's equalizing the freight rate applicable to competing mills in a manner similar to the Interstate Commerce Commission's ruling. In the absence of agreement establishing or maintaining such a system, it represented an attempt by each individual to meet competition.

In the Cement case, the manufacturers may or may not have been willing to sell on.an f. o. b. mill price. The opinion makes no mention of what the practice was. The petition, however, sets forth that: "Defendant corporations, without exception, make all sales f. o. b. point of delivery. . . ." 34 The decree of the District Court enjoined the manufacturers from agreeing to sell exclusively $f$. $o$. b. point of delivery. This decree was set aside by the higher court. This would lead one to believe that the Supreme Court did not consider sales f. o. b. manufacturing point a very decisive factor. Of course, this fact might be very influential, and it must be remembered that the Court did not in reality specifically pass on the question.

In the Maple Flooring and the Cement cases the Supreme Court went so far as to approve specially the gathering and dissemination of information with reference to the transportation costs from the chief points of production, although such information certainly tended to maintain the industry

34. Decree of District Court, par. 9 (c). 
custom of using basing-points, on the ground that it was an aid to quick and accurate price quotation. ${ }^{35}$

The freight problem in the recent Sugar Institute case ${ }^{36}$ was complex in form, ${ }^{37}$ and the District Court found an agreement to adhere to a delivered-price system. Although the defendants waived their assignment of error on this point in order to reduce the issues, the Supreme Court stated that the delivered prices were not arrived at pursuant to an agreement but that the defendants had agreed to maintain the delivered-price system.

The Court then found that this "concerted maintenance of delivered prices constituted undue and unreasonable restraint of trade." 38

In two other Supreme Court cases there were systems involving freight zones or basing-points. In American Column \& Lumber Co. v. United States, ${ }^{39}$ although the members of the Hardwood Lumber Association used a basing-point system, ${ }^{40}$ neither the briefs nor the opinion mentioned it. In United States $v$. American Linseed Oil Co., ${ }^{41}$ the record disclosed the existence of a zoning system substantially similar to a basing-point system, and Solicitor General Beck laid considerable stress upon its obviously artificial character. ${ }^{42}$ The Court found an actual agreement in restraint of trade so that it did not have to consider freight zoning per se. It did, however, make a passing reference to the existence of a freight-rate zone system. ${ }^{43}$

35. The Court in the Cement case recognized that such basing-point systems are an aid to quick, accurate price quotations, when it stated: "Prompt quotation of a delivered price therefore involves the ability to carry out promptly the mechanical process of adding to the mill price the cost of transportation to the point of delivery. Lists of freight rates, in convenient and readily available form, are therefore necessary adjuncts to the quotation of delivery prices for cement." 268 U. S. 588,598 (1925).

The Federal Trade Commission, however, arrives at the astounding conclusion that delivered prices do not simplify the calculation of freight charges. Thus it states: "The fact that the industry will sell only on a delivery price basis leads to interminable complications in the calculation of delivery charges." Fed. Trade Comm., supra note 1 , at 24.

36. Sugar Institute v. United States, 297 U. S. 553 (1936).

37. References to the freight problem (including an agreement not to make allowances for shipping by differential routes) are to be found in the pleadings and decree of the Sugar Institute case at the following places: Petition, pars. 20-33, pp. I0-I4; Answer, pars. I9-32; Government Brief in District Court, pp. 239-293; Defendant's Brief on the facts in District Court, pp. 202-238; Government Reply Brief in District Court, pp. 182-189; Findings in District Court, pars. 87-13I, pp. 38-58, especially pars. 105-I 13, pp. 45-50; Order in District Court, par. IV, 18-20, pp. 5-6; Defendant's Brief in Supreme Court, pp. 224-246; Government Brief in Supreme Court, pp. I24-I7I, especially at pp. I39-I59; Defendant's Reply Brief in Supreme Court, pp. 90-94.

38. 297 U. S. 553,590 (1936).

39. 257 U. S. 377 (I92I).

40. See Transcript of Record on appeal to the Supreme Court, pp. 33-40.

4I. 262 U. S. 37 I (I923).

42. See Brief for United States, pp. 3 I et seq., I42. Note also the references in Brief for Ankeney Linseed Co., pp. 20, 36, 56, and Brief for Am. Linseed Oil Co., p. I2.

43. "The United States was divided into eight zones for price quoting; and it was stipulated that each member should quote a basic price for zone number one and should add thereto one, two, four, six, seven, eight and eleven cents respectively, for the others." United States v. American Linseed Oil Co., 262 U. S. 371, 386 (I923). 
Consent decrees have been entered in two cases involving destination freight systems. United States $v$. Bolt, Nut \& Rivet Manufacturers Ass' $n^{44}$ involved an agreement to use arbitrary basing-points for the quotation of freight rates. The consent decree enjoined the agreement, ${ }^{45}$ and also enjoined "individually . . . charging on account of such freight rates as costs of transportation any amount at substantial variance from the actual cost of such transportation where such charge or charges will result in an unlaw ful discrimination in price". A consent decree was also entered in the case of United States $v$. Corn Derivatives Institute. ${ }^{46}$ The petition charged that "The defendants . . . agreed to adopt and have concertedly adopted Chicago, Illinois, as an arbitrary freight basing-point from which they compute and charge freight in addition to the quoted prices, regardless of the point from which Members actually ship Products." ${ }^{47}$ The consent decree is directed solely at an agreement, combination, or conspiracy to use a delivered-price system. ${ }^{48}$

In Standard Sanitary Manufacturing Co. v. United States ${ }^{49}$ the defendants were enjoined from continuing their agreements to monopolize and re-

44. District Court for the Southern District of New York, petition in Equity No. 53-383. The decree was entered March I7, I93I.

45. This decree further provides with reference to the agreement covering freight:

"That the defendants, . . . be and they hereby are perpetually enjoined, restrained and prohibited: . . ( ) From agreeing . . . to establish or maintain, or concertedly establishing or maintaining, the basing point system which includes Pittsburgh, Pa., Cleveland, Ohio, Birmingham, Ala., and Chicago, Ill., as the only base points . . .; (j) From agreeing . . . to refuse or concertedly refusing or concertedly failing to sell or quote prices . . . f. o. b. point of manufacture when requested so to do by the purchaser or prospective purchaser thereof; . . ."

46. District Court of Illinois, petition filed and decree entered April 6, I932.

47. At par. 3I. It is further alleged that: "In accordance with a mutual understanding among defendants, each Member has refused to quote prices for, or to make sales of, products f. o. b. factory or on any basis other than f. o. b. Chicago; . . ."

48. Par. 4 of the consent decree provides:

"That the defendants . . . be, and they hereby are, permanently and perpetually enjoined and restrained . . .

(b) From arranging, agreeing, entering into any understanding or otherwise acting in concert' ...

10. To refuse to quote prices for products $f$. o. b. point of manufacture, or to refuse to sell products at prices to apply at the point of manufacture."

49. 226 U. S. 20 (I9I2), aff'g I9I Fed. I72 (D. Md. I9II). The zoning system aimed at in this case was primarily a dividing of the country into exclusive selling territories. The petition in equity contained the following allegations of the existence of a freight zoning system in par. 3 :

"The defendants have divided the United States into certain territorial or geograph-

ical zones, and by their system of contracts are restricting each jobber in making sales to

the zone in which that jobber is located; in other words, the arrangement is such that no jobber is allowed to sell outside his zone."

In the criminal actions of United States v. Standard Sanitary Mfg. Co., Indictments Nos. $5 I 63$ and $5 \mathrm{I} 64$ (E. D. Mich.), both filed December 6, IgIo, there were allegations to the effect that the defendants had employed freight zones in order to maintain resale prices. The allegations are found in the First Indictment (No. 5163 ) in the fourth count, at page $7 \mathbf{I}$, and state that the defendants agreed that: 
strain trade. In that case one of the elements of the agreement was the division of the United States into eleven freight zones for pricing purposes. ${ }^{50}$ In a similar equity action against the Quaker Oats Company an injunction was not secured because of the insufficiency of the proof. ${ }^{51}$

There can be little question that in most instances the courts would hold that any agreement to use a freight destination system was a violation of the Sherman Act. The agency contract of the Appalachian Coal Company, which was sustained by the Supreme Court, ${ }^{52}$ apparently contemplated that the agency would fix a uniform delivered price for the products of the one hundred and thirty-six individual coal producers so that the competition between individual members would not rest on geographical position. The plan, however, contemplated competition between the grades of coal sold by the agency. ${ }^{53}$ Basing-point and freight-zone price systems do not violate the Sherman Act unless they are imposed or maintained as the result of an agreement, combination, or conspiracy which unduly restrains trade or tends to create a monopoly.

“. . . the said United States was to be divided by the said defendants into eleven territorial zones, the exact details of which said territorial zones are to the grand jurors as yet unknown, except that all of the said corporations, partnerships and individuals who were situated in any one zone were to resell at the same prices in said zone said sanitary enameled iron ware in said commerce."

There are similar allegations in the Second Indictment (No. 5164) in count 5, at p. 54, and count 6, at p. 77. The criminal actions against the Standard Sanitary Mfg. Co. came before the courts in I87 Fed. 229 (E. D. Mich. I9Ir). The question involved was whether or not the defendants had secured immunity by testifying in the equity case in Maryland. After a trial lasting 6 weeks, the jury reported a disagreement on March I4, 1912. At a retrial in February, I9ז3, the defendants were found guilty and fines aggregating $\$ 51,007$. were imposed.

50. Facts with reference to the zoning systems in Standard Sanitary Mfg. Co. v. United States, 226 U. S. 20 (I9I2), are set forth in the Government's Brief before the Supreme Court, p. 31 et seq.

5I. The case of United States v. Quaker Oats Co., 232 Fed. 499 (N. D. Ill. I9r6), involved an equity petition filed by the Government on June II, I9I3. The petition alleged a combination to restrain and monopolize interstate commerce in oatmeal and by-products therefrom. The petition itself does not set forth the existence of a delivered price system, but the brief on behalf of the Quaker Oats Co. attempts to justify the existence of such a system on the grounds that it "did not put the wholesaler at a disadvantage in competing with some other wholesaler at a different point in common territory who, by reason of a somewhat lower freight rate, might resell goods at a lower price from the same mill if this arrangement were not in existence." Petition, at p. 7r. The practice of the Quaker Oats Co., and at least one of its competitors, involved the maintenance of a uniform freight charge from their points of production to a group of cities, although the actual freight rates to those cities were not uniform. The cities involved were supposed to be places from which wholesale houses were competing against each other for sales in a common territory.

The case was argued before the Circuit Judges in March I9I6, and decided adversely to the Government. An appeal to the Supreme Court was dismissed upon the Government's own motion. 253 U. S. 499 (I920).

The case of United States $v$. Corn Products Refining Co., cited and discussed infra page 704, was held to involve a combination in restraint of trade amounting to a monopoly, but the zone system in question was found not to discriminate between purchasers.

52. Appalachian Coals v. United States, 288 U. S. 344 (1933).

53. The basic agency agreement provided that the price of coal would be fixed by the corporate selling agent (Finding of Fact No. 48a). See Brief for Appellant in the Supreme Court, pp. 35-37. 


\section{The Clayton Act}

There have been no cases in the federal courts where the precise question was whether such freight systems amounted to discriminations in violation of the old Section 2 of the Clayton Act. ${ }^{54}$ The complaint in In the Matter of United Steel Corporation ${ }^{55}$ charged violation of both the old Section 2 of that Act and of Section 5 of the Federal Trade Commission Act. ${ }^{56}$ In view of the Robinson-Patman Act, ${ }^{57}$ it will be necessary to deal first with cases arising under the old section, and then with the question as to whether the Robinson-Patman Act broadens the law against discriminations so as to cover this question.

The Maple Flooring and Cement cases, which were treated at length under the discussion of the Sherman Act, give some insight into the problem of the reaction of the courts to the question of the validity of basing-point systems under the Clayton Act. In view of the Supreme Court's language it is difficult to believe that such systems would be held to be discriminatory. In both cases the Court went to considerable length to justify the practices of supplying information which would be useful only in the operation of basing-points in these industries and points out the logical basis for the existence of such systems. The reasoning applied by the Supreme Court in these cases will apply equally well to freight-zone and delivered-price systems. Thus the case of United States v. Corn Products Refining Co. ${ }^{58}$ involved a petition in equity to enjoin a combination in restraint of trade. The court, while entering a decree dissolving the Corn Products Refining Company on the ground that the combination amounted to a monopoly, discussed the contention that the activities of the defendants had resulted in a discrimination in prices. Judge Learned Hand held that a zone system if equitably organized need not result in an actual discrimination in price although it might theoretically appear to do so, saying:

"I can find no evidence of the misuse of the so-called 'zone system', a system which in itself is entirely capable of equitable application. . . In general, I find the evidence too scanty to justify any finding that the defendants have attempted a genuine price discrimination, though they unquestionably had it in their power to do so." 59

54. 38 Stat. 730 (I9I4), I5 U. S. C. A. § I3 (I927).

55. 8 FED. TRADE COM. DEC. (r924) I. This case will be discussed infra under the treatment of the Federal Trade Commission Act, since it never reached the courts.

56. 38 Stat. 717 (I914), I5 U. S. C. A. \& 45 (1927). The pertinent portions provide: "That unfair methods of competition in commerce are hereby declared unlawful . ."

57. Supra note 13 .

58. 234 Fed. 964 (S. D. N. Y. I916). The petition in that case does not specifically involve a charge of geographical price discrimination, but merely alleges the existence of an illegal combination. It then proceeds to specify certain alleged unlawful and unfair acts of the defendants. Even in this specification no mention is made of the fact that zones amounted to unfair competition.

59. Id. at 994 . 
There could be little doubt but that if proceedings had been brought under the old Section 2 of the Clayton Act, such freight practices would have been justified in most cases by the proviso allowing a seller to meet competition in good faith. ${ }^{60}$

The Congressional debates on the Clayton Act reveal no references which could be interpreted as showing an intention to outlaw freight destination practices. The purpose of Section 2 seemed to be to prevent sales below cost or sales at a lower price in the community of their rivals than at other points throughout the country, in order to drive out competitors and thus to achieve a monopoly position. This was well expressed by Representative Floyd of Arkansas in the Congressional debates. ${ }^{61}$

As further evidence of this fact more comprehensive provisions for Section 2 were suggested as amendments; thus "discriminate in price" was proposed to be amended to read "discriminate in price, terms or otherwise", in order to broaden the operation of the section. ${ }^{62}$ Another amendment of Section 2 was proposed by Senator Clapp of Minnesota, ${ }^{63}$ providing that anyone

"selling a commodity at a lower rate in one section, community, or locality than is charged for such commodity by said party in any other section, community or locality, after making due allowance for the difference, if any in the actual cost of transportation from the point of production if a raw product, or from the point of manufacture if a manufactured produce (product), shall be deemed guilty of unfair discrimination ... (Italics added)

The defeat of this amendment to Section 2 is a sound ground for asserting that Congress did not intend to go as far in the statute enacted as the proposed amendment went. ${ }^{64}$ It should also be pointed out that congressmen repeatedly referred to the practice of the Standard Oil Company and other large companies in selling at a uniform price for an entire state, and yet they never once suggested that Section 2 would operate to change this situation.

60. The proviso states: "Provided, That nothing herein contained shall prevent . . . discrimination in price in the same or different communities made in good faith to meet competition." 38 Stat. 730 (1914), I5 U. S. C. A. \$13 (1927).

61. "The provision is in plain language and seeks to prevent dealers from lowering the price of commodities in different sections and communities by unfair discrimination with the intent and purpose to destroy, ruin, or injure the business of a competitor. That is a recognized evil extensively practiced by great and powerful concerns to drive out competition and destroy competitors, which results to the serious detriment of the general public, and has been demonstrated to be a most effective means in acquiring a monopoly. It does that and nothing more, and is not intended to do anything more." 5 I Cong. REc. 9158 (19I4). See also id. at 9260, 9263-9264, 9552, 9595, I4208-I4209, I4228, I4250.

62. Id. at 9265 . Note the amendment by Representative Morgan of Oklahoma, which is set forth in full together with comments thereon.

63. Id. at 14252-I4253, I4597-I4598.

64. Id. at 14597 . 
The only statement made in the Congressional debates that would lead one to conclude that freight destination systems were not to be protected, even excluding the right to meet competition, is found in one remark of Representative Helvering of Kansas, ${ }^{65}$ which is explainable on other grounds: ". . . this practice will be absolutely prohibited, for the same price will have to govern in every State, plus, of course, the difference in cost of transportation." It is believed that this statement was not intended to eliminate the possibility of freight destination practices, but rather to explain that prices might vary to the extent of actual transportation charges.

The wording of the Clayton Act in the old Section 2 itself lends support to an argument that there is actual "discrimination" when customers are given prices which make allowance for difference in shipping costs. Section 2 acknowledges legal "discrimination" to include ". . . discrimination in price between purchasers of commodities . . . that makes only due allowance for difference in the cost of selling or transportation . . ." The wording is not conclusive, however, in view of the fact that the competitive evil of discrimination as originally envisaged by the Clayton Act lies in the different positions in which customers are placed in their competition with other customers, by the differing treatment accorded them in prices, terms and allowances. Discrimination did not depend upon the difference in net profit or net revenue which the seller realized from his various customers. The result of the trend of the arguments against freight systems is that the equalization of the profit to the seller is essential to the removal of discrimination between customers. Viewed from that angle their argument is not a very compelling one. ${ }^{67}$ This real discrimination which exists today under freight destination price systems is based upon the fact that, as a result of a delivered-price system, customers located at or near the place of manufacture or shipment (or in that part of a freight zone nearest to the point of manufacture or the basic zone) are deprived of the advantage of such location and often are required to contribute to the cost of transportation of more distant customers, even though such customers frequently are in competition with each other.

Although such freight systems must of necessity result in discriminations when considered from the point of view of pure economic theory, yet the old Section 2 of the Clayton Act was aimed at discriminations unreasonable in extent which tended to create a monopoly. It was certainly not directed at old practices which were reasonably necessary to the carrying on

65. Id. at $9 \mathrm{r} 84$.

66. 38 Stat. 730 (I9I4), I5 U. S. C. A. \$ I3 (I927).

67. American Can Co. v. Ladoga Canning Co., 44 F. (2d) 763 (C. C. A. 7th, 1930), cert. denied, 282 U. S. 899 (I93I), held that Section 2 of the Clayton Act applied to a discrimination which gave to one consumer a price advantage in a material factor which was not given to competing consumers. See also Van Camp \& Sons Co. v. American Can Co., 278 U. S. 245 (I929). 
of efficient business and which did not tend to create a monopoly, or to practices which were adopted in good faith to meet competition. It is easily conceivable that some freight systems might be of such an artificial and unreasonable nature that they could not be sustained on any ground except that they were necessary to meet competition.

\section{The Robinson-Patman Act}

Heretofore, one of the chief bases for justifying delivered-price systems has been found in that part of the old Clayton Act which is now repealed, ${ }^{68}$ at least in its old form, and which specifically recognized the right to quote different prices in good faith for the purpose of meeting competition. The Robinson-Patman Act ${ }^{69}$ now raises a question as to whether such destination prices are permissible or whether they constitute unlawful price discriminations. ${ }^{70}$

The Robinson-Patman Act as finally approved contained no special reference to the freight situation. It is significant, however, that a number of the proposed amendments to the old Clayton Act specifically covered this controversial point. ${ }^{71}$ Thus the Patman Bill, as reported by the House, provided "That the words 'price', as used in this section 2 , shall be construed to mean the amount received by the vendor after deducting actual freight or cost of other transportation, if any, allowed or defrayed by the vendor." 72 The Utterback Bill contained similar language. ${ }^{73}$ It is apparent that such a provision would probably eliminate this problem provided that a person could not in good faith meet competition, since no discriminations

68. 38 STAT. 730 (I9I4), I5 U. S. C. A. § 13 (I927). See supra note 60 for the pertinent proviso.

69. Supra note I3.

70. Many trade associations whose members manufacture and sell diverse types of products have compiled questions with reference to the effect of the new section 2 of the Clayton Act. Considerable interest was shown in the question of whether the new law affected the delivery charges. Sellers wanted to know whether the Act required uniform freight terms, or whether it required selling on an $f . o$. b. mill basis. The question most often asked was: "Is selling on a delivered price basis to customers located at unequal distances from the point of supply prohibited?"

7I. It is difficult to ascertain the origin of the Wheeler and Utterback Anti-Basing-Point Bills, supra note 2, but they seem to express ideas that have long been promoted by the Federal Trade Commission. They may have developed as the result of the controversy between NRAi and the Federal Trade Commission in regard to the operation of the code for the Iron and Steel Industry (see Federal Trade Commission report on this subject, supra note 8) during which time the Commission strenuously attacked the basing-point system in the steel industry. Considerable impetus was probably given to these bills by the activities of municipal purchasing agents, and such officials as Secretary Ickes. See N. Y. Times, April 10, I936, p. 9, col. 2, as to Boulder Dam bids on wire and cable. It is insignificant that the items bid on in this incident were patented products covered by license agreements which compelled the quotation of a uniform price, since the item represents the present attitude of some government officials.

72. H. R. 8442, 74th Cong., 2d Sess. (1936), as reported March 3I, I936, p. 7, lines 20-23. This definition of price was eliminated on the floor of the House, 80 CoNG. REc. 8223-8224 (I936). $(1936)$.

73. H. R. 10486, 74th Cong., ad Sess., introduced January 22, 1936, 80 CoNG. Rec. 2889 
in price were allowed by virtue of the other provisions of the Act. ${ }^{74}$ There can be no doubt that such was in fact the intent of proponents of these provisions. ${ }^{75}$

Congress deliberately rejected the attempt to prohibit systems of selling upon a delivered-price basis either throughout the entire United States or by zones. The proposal provoked considerable opposition, ${ }^{76}$ especially among farm leaders as well as from a number of industries. The House Judiciary Committee eliminated this provision with the statement that otherwise the Act could not be passed; ${ }^{77}$ and a number of Congressional leaders expressed their opinion that the new law did not affect the basing-point system. ${ }^{78}$ In submitting the conference report on the Robinson-Patman Bill, Representative Utterback was careful to define "discrimination" so as to avoid much, if not all, of the delivered-price controversy. He said,

"In its meaning as simple English a discrimination is more than a mere difference. Underlying the meaning of the word is the idea that some relationship exists between the parties to the discrimination which entitles them to equal treatment, whereby the difference granted to one casts some burden or disadvantage upon the other. . . . But where no such relationship exists, where the goods are sold in different markets and the conditions affecting those markets set different price levels for them, the sale to different customers at those different prices would not constitute a discrimination within the meaning of this bill." 79

When the delivered-price provision of the Patman Bill was eliminated, in order to assure the passage of the balance of the bill, a new one was introduced, the Wheeler Anti-Basing-Point Bill, ${ }^{80}$ which was intended to cover completely the entire subject of freight allowances. As a result of this legislative history it may be argued with some considerable degree of

74. It is apparent that the purpose of the provision was to prevent a company from quoting a destination price to one customer which, after deducting freight rate, would result in a net price to the seller which was different from the net price received in a sale to a different buyer. It should be noted, however, that one of the items of proof which would have been required under this bill was that discrimination must be shown "substantially to lessen competition or tend to create a monopoly in any line of commerce, or to injure, destroy, or prevent competition with any person who either grants or receives the benefit of such discrimination, or with customers of either of them." H. R. REP. No. 2287, 74th Cong., 2d Sess. (1936) 14.

75. The report of the House Judiciary Committee on the Patman Bill, H. R. REP. No. 2287 , 74th Cong., 2d Sess. (1936), at p. I4, states with reference to this provision: "In effect, this provision of the bill is designed to put an end to price discrimination through the medium of the basing-point or delivered price system of selling commodities. It will require the use of the f. o. b. method of sale."

76. Statement by Citron, 80 Cong. Rec. 8223-8224 (1936); see also id. at 8122-8123 and 8I26-8127.

77. Statements by Boileau, 8o CoNG. Rec. 8122-8123 (1936), and id. at 7760 .

78. Statement by Borah, 80 CoNG. REC. 9903-9904 (1936), and id. at 8223-8224, 8I228123, and 8126-8127.

79. 80 ConG. REc. 9416 (1936). There are other expressions to the same effect at id. 8223-8242.

80. Supra note 2 . 
effect that the amended Clayton Act was not intended to broaden the operation of the old Section 2 on freight practices, and that the law does not require the measurement of price discrimination in terms of "mill net" or "factory" prices. "Price" will probably be construed as the amount paid by the buyer. An examination of the statute, however, reveals that without this legislative history a court might have listened more attentively to the argument that there was discrimination, in view of the apparent elimination of the general proviso which allowed a seller to meet competition in good faith.

In view of the proviso in Section 2 (b) ${ }^{81}$ allowing a seller to meet an equally low price of a competitor, it has been suggested that the amended statute would require manufacturers to sell on some sort of a basing-point system according to which the factory (or warehouse) of each competitor could be used as a basing-point with the competitor's price at his factory being the basing-point price. Such an interpretation depends on the statute allowing a seller to discriminate in price among purchasers from him, provided he is meeting an actual price quoted by a competitor. ${ }^{82}$

It is felt that in view of the fact that Congress eliminated a specific provision covering freight applications before passing the amended Clayton Act, and also in view of the attempt to cover this subject by a separate specific bill, a court would probably hold that such freight systems were not discriminatory per se, but that each case must stand on the particular facts involved in any given industry.

The Federal Trade Commission has recently issued a complaint against the "Birmingham-Plus" system employed by certain cast iron pipe manufacturers. ${ }^{83}$ 'One of the counts in this complaint charges that an agreement

8r. The pertinent proviso is :

"Provided, however, That nothing herein contained shall prevent a seller rebutting the prima facie case thus made by showing that his lower price or the furnishing of services or facilities to any purchaser or purchasers was made in good faith to meet an equally low price of a competitor, or the services or facilities furnished by a competitor." 49 StAт. I526, I5 U. S. C. A. \& 13 (b) (Supp. 1936).

82. There was discussion in both houses as to the effect of the new proviso compared with the old. See Senator Van Nuys' remarks, 80 CoNG. REc. 9903-9904 (1936), and Representative Utterback's, id. at 9418. They both maintain that the present proviso is a rule of evidence, and does not affect the substantive provisions of the act. This view is difficult to understand, and will have to be clarified by the courts. See also Federal Trade Comm., Data in Connection with the Robinson-Patman Act (1936) 22-24.

83. In Matter of Cast Iron Pipe Association, Fed. Trade Comm. Docket No. 309I (complaint issued March 26, I937), the complaint in two counts charges, first, that the respondents agreed to employ a "single basing-point system" of pricing which was operated on a Birmingham-Plus basis; and second, that this agreement and the practices pursuant thereto resulted in price discrimination under the Robinson-Patman Act.

The theory on which the "Birmingham-Plus" system is attacked is set forth in Count II, par. 6 , where it is alleged that delivered prices are not the actual prices received by respondents. This complaint is, therefore, based on the theory that in order to comply with the Robinson-Patman Act each manufacturer must inaugurate a pricing system with a single base price at his point of manufacture (or at his warehouses), to which would be added the actual freight to the destination of each customer. 
to utilize and the utilization of a basing-point system amounts to a violation of the Robinson-Patman Act. We may expect, after a decision of this case, that the question of whether or not a basing-point system is illegal under the Robinson-Patman Act will be determined.

It should be pointed out that if it were held that the Robinson-Patman Act were applicable to destination freight systems, they would probably not be illegal per se, but a question of fact would arise in each specific case upon the question of whether the buyers were in competition with other buyers from, or competitors of, the seller. The discrimination would, therefore, be actionable only when someone is hurt in his business or, in the language of the Act, "where the effect of such discrimination may be substantially to lessen competition or tend to create a monopoly in any line of commerce, or to injure, destroy, or prevent competition with any person who either grants or knowingly receives the benefit of such discrimination, or with customers of either of them". ${ }^{84}$ If no person or no line of competition is hurt, then the act is not illegal. Of course, where buyers are in different markets it is not likely that anyone will be injured by any such freight price systems. In addition, a seller may still meet competition at destination, and thus such freight systems may still be used under proper circumstances.

Some arguments may be made that no discrimination whatsoever exists in the case of a flat delivered price system in view of the uniformity of price, and apparently these arguments would apply in the zone situation only if the buyers in one zone were not in competition with the buyers in another zone, or if the difference in zone price is a function of, or proportional to, the actual freight rate. ${ }^{85}$

The legislative history of the Robinson-Patman Act and the proviso apparently condoning the meeting of a price of a competitor will probably be sufficient to justify freight-destination price systems under the Act. It must be remembered, also, that the delivered-price and analogous problems do not arise in any form where "competition", as defined in the Act, is not affected.

\section{Before the Trade Commission}

In I924, the Federal Trade Commission ordered the United States Steel Corporation ${ }^{86}$ and others to cease and desist from selling its rolled steel products at a Pittsburgh price plus freight from Pittsburgh, on the ground that this practice constituted a violation of Section 2 of the Clayton Act, and that it was an "unfair method of competition" under Section 5 of the Federal Trade Commission Act. ${ }^{87}$ The reasoning of the Commission

84. 49 STAт. I526, I5 U. S. C. A. \& I3 (a) (Supp. 1936).

85. See Kavits, Analysis of Neze Section 2 of Clayton Act made for National Paper Trade Ass'n, Inc., N. Y. Times, July 20, I936, p. 22, col. I.

86. Matter of United States Steel Corp., 8 FEd. Trade CoM. Dec. (Ig24) I.

87. Supra note 56. 
was that a manufacturer, by adopting such delivered-price policies, was "unfairly" discriminating among customers. ${ }^{88}$ It was found as a fact that the discriminations under Pittsburgh-Plus were not made for any of the purposes permitted by the Clayton Act, and the Commission specially stated that "The prices thus made were not and are not made in good faith to meet competition in different localities and communities". 89 It also found in reference to Pittsburgh-Plus prices that "Pittsburgh-Plus adds millions of dollars each year to the price paid by steel users outside of Pittsburgh, which of course, must be eventually paid by the public." 90

Commissioner Gaskill wrote a vigorous memorandum of dissent in this action, in which he found no legal basis for the cease and desist order. $\mathrm{He}$ stated that he felt that the question was one for legislative correction, ${ }^{91}$ and that the Federal Trade Commission was going beyond the jurisdiction granted to it by Congress. The dissent is also based on the theory that the Federal Trade Commission Act does not establish a standard of absolute freedom of competition, but allows the observance of sound economic principles. ${ }^{92}$

The respondents never attacked the validity of the Commission's cease and desist order, but issued an announcement that, without conceding the validity of the order, they had determined to conform thereto in so far as practicable. As a matter of fact even before the order was issued the United States Steel Corporation had found it inadvisable to adhere strictly to the Pittsburgh basing-point system. Birmingham, Alabama and Chicago were added as basing-points. Additional basing-points for different steel and iron products were added, so that Cleveland, Worcester (Mass.) and Duluth were added for wire products. Steel tubes had basing-points at Pittsburgh, Lorain and Youngstown, Ohio, Wheeling, W. Va., and Chicago.

Although products were no longer quoted solely on a Pittsburgh base, it appears that the delivered price generally quoted was in fact equivalent to the old Pittsburgh-Plus price. Thus, while the mechanics of PittsburghPlus were generally modified, prices persisted at levels progressively higher

88. In Matter of the United States Steel Corp., 8 Fed. Trade Com. Dec. (Ig24) I, 20 the Findings of Fact, in par. $6(\mathrm{~h})$, state this discrimination in these words: "The respondents, in selling their respective steel products from their mills outside of Pittsburgh at Pittsburgh Plus prices discriminate among the customers of the same mill. In the case of two steel users buying steel from the same mill outside of Pittsburgh, that steel user whose plant has a less freight rate from Pittsburgh secured a less price from the respondent than his competitor whose freight rate from Pittsburgh is greater. In other words, the actual freight rates from the producing mill to the customers' plants do not determine the difference between the delivered prices paid by customers buying steel from the same mill."

89. Id. at 38 .

go. Id. at 35 .

9I. "If the economists are right, the requirements of the situation will be met only by a legisiative recognition of the necessity for a more exact statement of the scientific relation between business and economics and the declaration of that relation in the form of a law of general application." Id. at 65 .

92. Id. at 62 . 
as the distance from Pittsburgh increased, and this although steel costs at both Birmingham, Ala., and Gary, Ind., were considerably below costs at Pittsburgh.

It is rather difficult to understand why the Commission has allowed the steel industry to continue such practices unmolested after its entry of the cease and desist order. It has been well aware of the workings of the steel basing-point systems and has published numerous pamphlets concerning this subject. ${ }^{93}$ It has issued four complaints against delivered-price practices in other industries. One complaint was dismissed, ${ }^{94}$ a second was settled by a consent, cease and desist order, ${ }^{95}$ and the other two are still pending. ${ }^{96}$ The Commission has also considered a basing-point system in a case alleging a Sherman Act conspiracy. ${ }^{97}$

In connection with proceedings before the Federal Trade Commission it is well to remember that the jurisdiction of that body is not entirely limited to violations of the Sherman and Clayton Acts, provided the ac-

93. Fed. Trade Comm. reports listed supra note 8. See also Fed. Trade Comm., Study of the Zone-Price Formula in the Range Boiler Industry, 1936.

94. Fed. Trade Comm. complaint Docket No. I46r, which charged that sales of range boilers were based "on a delivered and fixed lump sum basis . . ." was dismissed without reason given, May I, I93I.

95. In Matter of Nat'1 Electrical Mfrs. Ass'n, Docket No. 2565, the original complaint was issued September 26, 1935, the amended complaint on November I6, 1935, while the consent cease and desist order was entered December 29, 1936. Both complaints charged an agreement to use a delivered-price system. The findings of fact restated the allegations of the original and amended complaints with reference to delivered price, and the cease and desist order provided:

"IT IS Further ORDERED that said respondent corporations . . . cease and desist . . from doing and performing, by agreement, combination or conspiracy . . . the following acts and things: . . - (7) Refusing to sell any buyer who so elects at a price calculated $f$. $o$. b. point or place from which the goods purchased are actually shipped; (8) Requiring that customers purchase only on a delivered price basis, whether in the form of a single delivered price throughout the United States or throughout each of any number of price zones; . ."

96. Matter of Cast Iron Pipe Ass'n, cited and discussed supra note 83, and Matter of the Water Works Valve and Hydrant Group, Fed. Trade Comm. Docket No. 2958 (complaint issued October 29, 1936, and amended November 16, 1936). The latter case alleges that the respondents have ". . . agreed to divide . . . and have divided the United States into zones, in which zones the said respondents have by agreement fixed and maintained . $\cdot$ enhanced uniform delivered prices ..." Most of the respondents filed an answer on February I, I937, consenting to the entry of an order to cease and desist from any such agreement.

97. In Matter of North Dakota Wholesale Grocers Ass'n, 9 Fed. Trade Com. Dec. (I925) 266, the complaint charged the association with entering into an agreement or understanding to fix uniform prices at which its members were to sell their products. The complaint itself did not charge an agreement to use a basing-point or freight-zone system. The Commission found, however, that the respondents had entered into an agreement to fix and maintain prices, and that pursuant to said conspiracy they had agreed that sugar should be sold upon a common basing-point system. Price cards showing the agreed prices and freight books showing the freight to be added to the base price from the common basing-point were distributed among the respondents.

The Commission entered an order compelling the respondents to cease and desist from agreeing upon and maintaining uniform selling prices. The order did not specifically direct the respondents to cease and desist from using a basing-point system. The reason, perhaps, for not having done so probably is that the Commission felt that in the absence of an agreement to fix and maintain prices the basing-point system would cease to exist. 
tivities are "unfair methods of competition".98 In the main, "unfair methods of competition" have been limited to embrace only violations of provisions of law or already established common law rights. The Beech$N u t^{99}$ case, however, goes beyond these limits, but subsequent cases have not extended ${ }^{100}$ it beyond the original scope of the decision, which held that complex systems for checking upon a failure to sell at suggested resale prices may go so far beyond a simple refusal to sell to price cutters that they are illegal, and that such individual policing or check-up systems are illegal. In spite of the lack of authority on this situation, it is believed that the courts might well permit the Commission to extend its activities to include prosecutions of individual discriminations which, though legal under the Clayton Act, nevertheless amount to unfair methods of competition and clearly evade the intent of the Anti-Trust Laws though not contrary to their specific provisions.

The Federal Trade Commission has expressed itself against basingpoint and delivered-price systems on numerous occasions. ${ }^{101}$ Their expert economic witnesses are rabid against all freighting systems which are not based on the actual freight rate from the place of manufacture to the point of consumption. ${ }^{102}$ The Commission is probably correct in believing that a delivered-price policy results in an economic discrimination among customers. Thus some customers must purchase freight that they do not use :or else they must pay a higher initial cost, depending upon from which angle the process is viewed. This discrimination, of course, becomes less and less as charges made for freight approach actual freight costs.

Even assuming that such freight systems were "unfair methods of competition", ${ }^{103}$ by virtue of Federal Trade Commission $v$. Raladam ${ }^{104}$ the Commission can not proceed against any freight practices as unfair methods of competition unless proof can be given that such practice appears to threaten substantial injury to, or in fact does lessen, competition. The Raladam case would be a complete defense if there were no competitors, and it seems to offer a complete defense if all the companies in an industry voluntarily follow the same practice; no attack is open unless it is proved that (I) there is an agreement, or (2) that there is a discrimination which tends to create a monopoly.

98. Federal Trade Comm. v. Beechnut Packing Co., 257 U. S. 44 I (I922).
99. Ibid.

10o. The only apparent attempt to extend the Beechmut case to other factual situations was defeated in Federal Trade Comm. v. Western Meat Co., 272 U. S. 554 (I926), on the very special grounds that the Commission was specifically authorized to enforce Section 7 of the Clayton Act and hence could not go beyond the scope of the remedies therein provided for.

IOI. Supra note 8.

102. FETTER, op. cit. supra note II.

103. Federal Trade Commission Act, $\$ 5,38$ Stat. 7I9 (I9I4), I5 U. S. C. A. $\$ 45$ (I927). I04. 283 U. S. 643 (I93I). 
Under most circumstances it would be difficult to make out a case where delivered-price practices were "unfair methods of competition" unless they were clearly in no way reasonably related to freight costs and were not necessary to the meeting of competition, or unless they had in fact resulted and were resulting in a lessening of competition.

\section{CONCLUSION}

The Maple Flooring and Cement cases were treated at length because they represent the only times that freight destination questions have ever been seriously discussed by the courts. In the future the courts might hold other freight destination systems unreasonable discriminations and make a distinction between the basing-point systems used in the maple flooring and cement industries and those developed in other industries. From the Supreme Court's opinions in those two cases it is apparent that the basing-points were used for the purpose of facilitating the calculation of delivered prices and that they enabled manufacturers to know what mill-base price they would have to set in order to quote a competitive price at any given destination.

Whenever the points of manufacture are closely concentrated and the locations of basing-points are roughly central, and no single manufacturer is placed in a particularly advantageous competitive position, then the discrimination involved does not tend substantially to lessen competition, restrain trade, or create a monopoly. In addition, when the points of production are comparatively close to the points of actual shipment there is no systematic discrimination between customers. Since the chief consideration in both these cases was the legality of open price trade associations, it has been contended that the Court's apparent conclusion that there was no substantial discrimination is an ill-founded dictum based on a superficial analysis of the nature and possible effect of basing-point systems. Granted, however, that such policies are discriminatory, it does not follow that they can ipso facto be ruled out. It would have to be a discrimination so as "substantially to lessen competition or tend to create a monopoly". ${ }^{105}$ The purpose and effect of the freight destination policies in most industries does not seem to have resulted in monopoly, though it would seem that a complete uniformity in freight policy would eliminate geographical location of factories as an element in the competition between manufacturers. The Supreme Court has held that not all price discriminations are illegal. ${ }^{106}$ Such cases suggest the possibility of sustaining a freight destination policy, although discriminatory in character, on the ground that it was a necessary device in

105. Clayton Act, § 2, 38 STAT. 730 (I9I4), I5 U. S. C. A. \$ I3 (I927).

I06. Fairmount Creamery Co. v. Minnesota, 274 U. S. I (I927), which held that state anti-trust legislation could not forbid price discrimination made in good faith to meet competition, and that a purchaser could not be prohibited from paying a lower price in communities where competition did not exist and higher prices where it existed. Cf. Central Lumber Co. v. South Dakota, 226 U. S. I 57 (1912), where it was held that a state could regulate discriminating sales made for the purpose of destroying competition. 
order to meet competition. A seller could probably also justify his practices if he followed those of the industry leader, since the mere fact of following the leader does not make the practice an illegal restraint of trade. ${ }^{107}$ If, however, an actual agreement was proved among the sellers, there could be no justification of the practice on such grounds, or on any grounds except as indicated above in the discussion of the Sherman Act.

It is impossible even to outline the many factual variations which bear on the reasonableness of freight destination systems. Since no authority exists on the validity of one system as compared with another, it may be safely assumed that the courts will examine with diligence the reasonableness of any freight destination systems which come before them.

The difficulty of predicting the effect of the Robinson-Patman Act on this problem should be apparent. It should first be realized that the definition of "price" in the original Patman and Utterback Bills were not designed to eliminate the discriminations covered by the original Clayton Act. They were designed primarily to equalize the net profit or net revenue which a seller actually realizes from his various customers. Before a court should construe the Robinson-Patman Act to reach this result it should certainly re-examine the basis of the Act and also consider the possible effects of an interpretation which condemns freight price systems. If such an interpretation were made, it would result in many instances in destroying the equality of price to which groups of customers have been accustomed. The gain of one customer would certainly be the loss of another. It is unsound to examine delivered-price practices entirely from the point of view of whether or not one system or the other would have been preferable from the beginning; the fact must be faced that many businesses have been built up upon the principle of some freight destination system, and to disturb it now would risk such a vast dislocation of the normal channels of seller and customer that any predicted countervailing advantages should be closely scrutinized.

The answer to the question of whether there is substantial or unfair discrimination among competitors must rest in a large measure on the facts presented in a given case. It is safe to say, however, that the Supreme Court has dealt sympathetically with freight destination systems which were based on the stable custom of an industry and which appeared reasonable and justifiable on their facts. If the sole purpose of a freight destination system is artificially to extend the area in which a group of factories can profitably operate, the system is open to some criticism; but if its purpose is solely to meet competition in good faith, it is a reasonably justifiable business practice. The line between these two purposes is one which would be almost impossible to draw even in a concrete case. 